\title{
Parthian-Armenian Relations From the 2ND Century BCE to the Second Half of the 1st Century CE
}

\author{
Edward Dąbrowa \\ iD http:/orcid.org/0000-0002-9324-9096 \\ Jagiellonian University in Kraków
}

\begin{abstract}
The aim of this paper is to present Parthian-Armenian relations from the end of the 2nd century BCE to the so-called Treaty of Rhandeia $(63 \mathrm{CE})$. This covers the period from the first contact of both states to the final conclusion of long-drawn-out military conflicts over Armenia between the Arsacids ruling the Parthian Empire and Rome. The author discusses reasons for the Parthian involvement in Armenia during the rule of Mithradates II and various efforts of the Arsacids to win control over this area. He also identifies three phases of their politics towards Armenia in the discussed period.
\end{abstract}

Keywords: Armenia, Parthia, Arsacids, Rome, Parthian-Armenian relations.

As a result of the Roman-Parthian rivalry over Armenia, the period of the country's history from the 1 st century BCE to the 3rd century CE is among the best-known. We owe most of our knowledge of this period to the extensive accounts of ancient authors, who wrote at length on the various phases of this rivalry. Although not all these accounts have survived, those that are available contain a large amount of valuable data on Armenia's history, society and culture in this period. Yet the image of the state that these sources evoke has a major shortcoming - it is portrayed from the point of view of Roman authors, which was coloured above all by Rome's rivalry with the Parthian Empire, ruled by the Arsacid dynasty. Both empires aspired to dominate Armenia, in order to assure themselves a strategically beneficial position to allow them to defeat their opponent and assert their advantage. It is important to add that for Rome as well as for the Arsacids, achieving this advantage was of major significance for propaganda purposes.

The way in which Roman authors reported the course of the Roman-Parthian rivalry over Armenia gives us an insight in particular into the objectives and motives that guided Rome in its efforts both during the Republic and at the time of the Empire. Far less often, however, do they mention the motives of the actions of the opposing side. And yet, even despite their scattered nature, these references are extremely valuable as they allow 
us to understand the Arsacids' approach to the rivalry and its evolution over time. The Parthians were interested in Armenia much sooner than the Romans were, in the late 2nd century BCE, and it is therefore worth considering what the reason for this interest was, and why this region was so important for the Arsacids that they spared none of the methods and forces available to them to prevent it coming under Roman rule.

For a long time, scholars did not grasp the importance of this early Arsacid engagement in Armenian affairs. The first to do so was Józef Wolski, who regarded it as an important element of the external policy of the Parthian state. ${ }^{1}$ Thanks to the progress in research on the history of the Parthians and Roman eastern policy that has been made since this time, we now have a better understanding of the place of Armenia in the policy of the Arsacids, especially in the period beginning with the first contacts between Armenia and the Parthians and closing with the so-called Treaty of Rhandeia (63 CE), regulating the political-legal status of Armenia itself and its ruler. ${ }^{2}$

Armenia emerges as an independent state in the period after the Treaty of Apamea (188 CE), concluded with Rome by Antiochus III. Following the defeat of the Syrian ruler, resulted not only in severe financial sanctions, but also in the loss of a large part of the Seleucid lands in Asia Minor, as well as reducing or even stripping away his power over certain provinces in the eastern part of his state. One of these was Armenia, which took advantage of the favourable situation to become independent. The two strategoi administering Armenia at the time - Artaxias of the Orontid dynasty, who was responsible for the larger eastern part, and Zariadris, overseeing the much smaller western part (including Sophene) - assumed royal titles. ${ }^{3}$ Artaxias expanded the borders of his state and gained such an important position among local rulers that in $165 \mathrm{BCE}$ Antiochus IV decided to mount an expedition against him. ${ }^{4}$ This ended victoriously for the Syrian king, with the capture of Artaxias. ${ }^{5}$ Soon afterwards, however, he was released by Antiochus, and returned to Armenia. Yet this experience of defeat did not persuade him to abandon his ambitious plan to take control of all the Armenian lands, as the attempt to conquer Sophene after the death of its ruler shows. Artaxias wanted to take advantage of the help of Ariarathes V, king of Cappadocia, yet this plan was foiled, as his potential ally was also interested in conquering Sophene. Artaxias' alliance with Timarchus, satrap of Media, also failed to live up to expectations, as in $161 \mathrm{BCE}$ Timarchus focused his energies on a rebellion against the Syrian king Demetrius I. ${ }^{6}$ It is probable that Artaxias I died soon afterwards. The Artaxiad dynasty that he founded ruled over Armenia until the end of the 1st century BCE. Sources name Tigranes I and Artavasdes I among his immediate successors, but we know little about them or their rule. Even their

Cf. Wolski 1980 and 1983.

2 Because rules of the agreement from Rhandeia between Corbulo, Vologases I and Tiridates were respected for several decennia scholars use to name it the Treaty of Rhandeia. In fact, the agreement was never turned in form of diplomatic document formally approved and confirmed by all interested parties.

3 Strabo 11.14.15 (C 531-532).

4 Sachs - Hunger 1989, no. 164B, 'Obv.', l. B15‘; Del Monte 1997, 81.

5 Appian, Syr. 66.

6 Diod. 31.27a. 
dates are open to dispute. ${ }^{7}$ Yet the sources leave no doubt as to the fact that Armenia was a subject of Parthian interest during the reign of Artavasdes I. ${ }^{8}$

The Arsacid Empire reached the pinnacle of its power during the reign of Mithradates II (123-88 BCE), ${ }^{9}$ but the groundwork was laid by Mithradates I (171-132 BCE). When he ascended to the throne, the Parthian state was one of many lesser political entities recognising the authority of the Seleucids. Over the course of the next decade or two, however, it became an increasingly strong regional power, thanks to Mithradates I's expansion policy, which operated from the beginning of his rule. Contributing factors to this radical change in the significance of the Arsacid state were his numerous conquests, first in Central Asia and Iran, and then in Western Asia and Mesopotamia. The latter two allowed him within the space of several years to take control of the Seleucids' most important and valuable satrapies in the East: around 148 BCE he conquered Media, and in $141 \mathrm{BCE}$ his army occupied a large portion of Mesopotamia together with its main cities, Babylon and Seleucia on the Tigris. ${ }^{10}$ As a result of these acquisitions, all the borders of the Arsacid state shifted considerably, especially those in the west. Mithradates I's immediate successors were forced to concentrate on consolidating Arsacid rule in the already occupied territories and defending them from external threats. Only when Mithradates II was in power did the Parthian state's internal and external situation allow a return to its policy of expansion. His operations in the east resulted in the conquest of Bactria, ${ }^{11}$ and in the west the borders of Parthia were based on the line of the middle Euphrates, which was probably also linked to the Parthian capture of an area of northern Mesopotamia at least from Dura Europos all the way to the borders of Armenia. ${ }^{12}$

Mithradates II's aggressive actions towards Armenia are mentioned by Pompeius Trogus (Prol. 42) and Justin (42.2.6). ${ }^{13}$ References, some more direct than others, can also be found in Strabo. ${ }^{14}$ Although scholars have been well aware of these mentions, for a long time they did not show any great interest in them. Józef Wolski was the first to appreciate their true significance for reconstructing the history of Parthian-Armenian relations. The reason for the lack of interest in the information contained in them was Justin's reference to a Parthian ruler who mounted an expedition against Armenia, which suggests that this ruler must have been Mithradates III. According to scholars, attributing the conquest of Armenia to him contradicts what we know about his activity, and this

7 On the history of Armenia in the Hellenistic period, see Schottky 1989; Traina 2007, 108-119.

8 Cf. Pomp. Trogus, prol. 42; Just. 42.2.6.

9 Cf. Sachs - Hunger 1996, no. 90, 'Obv., ll. 30'-31'. Scholars disagree on the dates of his rule, which can vary even by several years, especially the end date, depending on the sources upon which they are based.

10 Cf. Debevoise 1938, 19-28; Dąbrowa 1998b (= Dąbrowa 2011, 39-47); Dąbrowa 2005 (= Dąbrowa 2011, 59-73); Dąbrowa 2006.

11 Olbrycht 2010, 150-155.

12 Cf. Strabo 11.9.2 (C 515); Just. 42.2.2-6. On the basis of papyrological and numismatic data, it is assumed that the Parthians' conquest of Dura Europos probably took place during his rule, between 116 and 113 BCE. The last document dated according to the Seleucid era found in Dura Europos comes from 116 BCE: Wells - Fink - Gilliam 1959, no. 34. According to A. R. Bellinger (1948-1949, 65-67), numismatic data allow us to assume that the Parthians occupied the city around $113 \mathrm{BCE}$. The correctness of the arguments in favour of this data has been called into question, however; cf. Edwell 2008, 101-102.

13 Cf. also Just. 38.3.1.

14 Strabo 11.14.15 (C 532). 
source was therefore deemed to be unreliable. ${ }^{15}$ Wolski, however, proved that Mithradates II did attack Armenia, as well as determining the likely date of his campaign. ${ }^{16}$ These conclusions were fully corroborated, as well as clarified in various aspects, by the data contained in the Babylonian astronomical diaries that became available to scholars decades after the publication of Wolski's findings. ${ }^{17}$

The sources show that in 110 BCE Mithradates embarked upon a campaign against Artavasdes, the result of which was that the Armenian ruler lost part of his territory to his neighbour and recognised his rule. ${ }^{18}$ The guarantor of Artavasdes' loyalty became Tigranes, a member of the royal family, who was made a hostage in the court of Mithradates II. ${ }^{19}$ Yet in none of these sources there is the slightest reference to the causes of the Parthian attack.

There is no doubt that the area of northern Mesopotamia occupied by Mithradates II, on which the two countries' borders met, was of strategic importance, as it gave the Parthians the opportunity to control the main passages on the Euphrates, leading from Mesopotamia into Commagene and Syria. From this point on, however, Mithradates also had to pay careful attention to events on the opposite bank of the river, in Anatolia. Rome was present in Asia Minor in political terms from the beginning of the 2nd century BCE, but for some time this presence was limited to arbitration between the Greek cities lying in the area. The situation changed markedly when the kingdom bestowed on Rome by Attalus III was converted into a province. Rome's interest in Asia Minor now took on a different character. The frequent interferences in the internal affairs of not only Greek cities, but also Hellenistic states existing in Anatolia could not go unnoticed. As long as the Arsacids' attention was directed towards Central Asia, as well as the southern part of Mesopotamia, Rome's actions in the eastern part of the Mediterranean basin were presumably of no interest to them; but the Romans' war with Antiochus III and its consequences, as well as later meddling in Syrian affairs, could hardly slip the Arsacids' attention. The situation in Cappadocia, lying north of Commagene, in whose internal matters Rome had interfered on a number of occasions in the second half of the 2nd century $\mathrm{BCE}$, was also a potential cause for alarm. Mithradates II certainly realised what a threat to the interests of his state a similar Roman interference in Armenia would mean, since its geographical location made it a "vestibule" of Mesopotamia, and thus the need to capture it in this situation was becoming a raison d'état. ${ }^{20}$ The king's fears of Roman expansion were not without justification. In the final years of the 2 nd century BCE, Roman soldiers had appeared in Cilicia to take part in the battles with pirates waged there be-

15 See Schottky 1989, 209-223.

16 Wolski 1980, 255-260, 264; Wolski 1983, 271; cf. Chaumont 1985-1988, 13-25.

17 Cf. Sachs - Hunger 1996, no. 110, 'Rev.', l. 14'; no. 95A, 11. 9'-12'; 95C, 'Obv.', ll. 5'-7'; no. 95D, 'Flake', 11. 10-11; Geller - Traina 2013, 447-448.

18 Sachs - Hunger 1996, no. 110, 'Rev.', ll. 13'-14'; Del Monte 1997, 154; Geller - Traina 2013, 449-450. The rather imprecise expression used to describe these areas, "seventy valleys in Armenia"

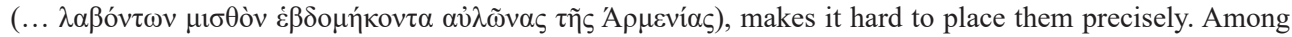
the more interesting proposals is the one presented by M.-L. Chaumont (1985-1988, 23-25); cf. Geller Traina 2013, 451.

19 Geller - Traina 2013, 450.

20 Cf. Börm 2019, 104-105. 
tween 102 and 100 BCE by M. Antonius Orator. ${ }^{21}$ Although this presence would turn out in fact to be only short-lived, Mithradates could not have known that. Several years later, in $96 \mathrm{BCE},{ }^{22}$ P. Cornelius Sulla appeared in eastern Anatolia, dispatched to Cappadocia by the Roman senate with the mission of placing the Rome-supported Ariobarzanes on the throne and continuing the operations against the pirates. ${ }^{23}$ Mithradates responded by sending Orobazes to him, a representation that was the first official diplomatic contact between representatives of the two states. ${ }^{24}$ In Mithradates' name, his envoy proposed an alliance to Sulla, as well as friendship between the two sides. ${ }^{25}$ Yet the Roman commander did not treat him with sufficient respect (at least in the view of Mithradates II, who had the ineffectual envoy put to death) ${ }^{26}$ and his behaviour towards Orobazes seems to suggest that he knew little about the Parthian state and its ruler's aspirations.

Given the lack of an agreement with Rome, Mithradates II was left with no choice but to protect his influence over Armenia. He did this in 95 BCE, after Artavasdes' death, by enthroning Tigranes, who had spent years at his court. ${ }^{27}$ Tigranes' return to his homeland was preceded by the dynastic marriage between his daughter Aryzate, also known as Automa, and Mithradates II's son, who went by the same name as his father and became known as Mithradates III. ${ }^{28}$ The idea was to strengthen relations between the two ruling houses, as well as laying the groundwork for potential Arsacid intervention in Armenia if the course of events there was inopportune for Parthian interests.

Mithradates II's death wiped out many of the achievements of his long reign. The Parthian state found itself in a profound political crisis caused by struggles between pretenders for the throne. Tigranes II exploited this situation to not only regain the parts of his state that he had lost to Mithradates II, but also to capture others belonging to the Arsacids. ${ }^{29}$ The weakness of the Parthian state also allowed him to strengthen his position in

21 Cf. Livy, ep. 68; Jul. Obseq. 44; Pompeius Trogus, prol. 39.

22 Scholars have long disputed the question of the year in which Sulla held the praetorship. This is important from the point of view of determining the time of his stay in Cilicia. The dominant opinion for a long time has been that Sulla was praetor in 93, and since he received a mission in the East the following year, it is reckoned that he was there in 92 BCE. Yet E. Badian demonstrated $(1959,280-287,303)$ that this belief was based upon false premises. According to him, Sulla held the praetura in $97 \mathrm{BCE}$, and was in the East in 96 BCE. Other scholars, analysing Sulla's senatorial career, provided arguments to support these conclusions: Liebmann-Frankfort 1969, 166-171; Sumner 1978, 395-396; Cagniart 1991, $285-291$.

23 Livy, ep. 70; Vell. Pater. 2.24; Plut. Sulla 5.3; Just. 38.2.8.

24 Plut. Sulla 5.4.

25 Livy, ep. 70; Plut. Sulla 5.4; Festus 15.2. The only source to mention any agreement between Sulla and Mitridates II is Florus $(2.46=3.11)$. Cf. Liebmann-Frankfort 1969, 173-176.

26 Plut. Sulla 5.4-5.

27 Sachs - Hunger 1996, no. 95A, ll. 9'-12'; 95C, 'Obv.', ll. 5'-7'; no. 95D, 'Flake', ll. 10-11; Strabo 11.14.15 (C 532); Del Monte 1997, 165-167; Geller - Traina 2013, 447-448.

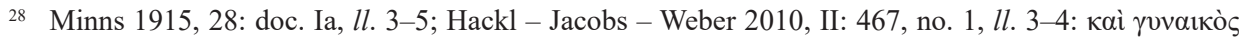

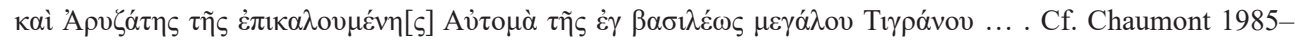
1988, 21-23; Sullivan 1978, 913-914; Huber - Hartmann 2006, 501. The identification of King Mithradates, mentioned in an Avroman document, has long been disputed. Various proposals for identification of this figure have been made in the course of this debate, along with different dating from that previously accepted; cf. Dąbrowa 2018, 77, note 24; Luther 2018, 155-170. The various doubts notwithstanding, however, it seems that the generally accepted dating of this document suggests that the person mentioned in it was indeed Mithradates III.

29 Debevoise 1938, 51. 
the region. Thanks to his alliance with the king of Pontus, Mithradates VI, consolidated with marriage to his daughter, ${ }^{30}$ Tigranes II soon turned Armenia into a regional power. Yet the Parthian state slowly began to rebuild its position during the reign of Sinatruces (77-70 BCE). The objective of the ruler's external policy was to regain the territories lost by the Arsacids after the death of Mithradates II. ${ }^{31}$ The position of the Parthian state at this time is demonstrated by the fact that even in 73 BCE, Mithradates VI approached Sinatruces requesting help in a war against Rome. ${ }^{32}$ Several years later (c. 69/68 BCE) he did so again, this time asking the then ruler Phraates III (70-57 BCE) to participate in a war with Rome. It was not just Mithradates VI who appealed to the Parthian monarch to take part in this conflict, but also Tigranes II. ${ }^{33}$ Despite these efforts, however, the king remained neutral. ${ }^{34}$ A little earlier, the Roman commander Lucullus had employed a stick-and-carrot method to seek Phraates' favour. On the one hand, he threatened him with attack if he should join the enemy camp, while on the other, he tempted him with the offer of a friendship pact. ${ }^{35}$ Ultimately, a lack of trust in Lucullus led Phraates to refrain from closer collaboration with him. ${ }^{36}$ It was a similar story in $66 \mathrm{BCE}$, when Pompeius took command in a war against Mithradates VI and Tigranes II. The new commander was also aware of the need to strike a deal with Phraates III, whose support both rulers in conflict with Rome were seeking, offering to surrender the parts of Armenia that were the subject of Parthian claims in return for his help. ${ }^{37}$ As a result, the agreement reached between Pompeius and the Parthian ruler included resolutions intended to persuade him to cooperate with the Romans: recognition of the Euphrates as the common border and Phraates III's right to possess those lands of Armenia that he had captured in the fight against Tigranes II. ${ }^{38}$ Even earlier, before the agreement with Pompeius and of his own accord, Phraates entered the succession-based conflict between Tigranes II and his son, Tigranes the Younger. ${ }^{39}$ So violent was this dispute that it became a civil war. The defeated Tigranes the Younger left Armenia and sought refuge in the court of Phraates III, who promised him help on the condition that Tigranes would marry his daughter. As the father-in-law of the Armenian heir to the throne, he was counting on having a justification for getting involved in Armenia's internal affairs. ${ }^{40}$ The marriage probably

30 Appian, Mithr. 104.

31 Cf. Memnon 38.6 (=FGrH IIIB, p. 366).

32 Memnon 29.6 (=FGrH IIIB, p. 359).

33 Sallust., Hist. 4.69.1-23; Memnon 38.6 (= FGrH IIIB, p. 366); Appian, Mithr. 87; Cassius Dio 36.1.1-2; 3.1.

34 Appian, Mithr. 87. It is worth noting that among the factors that determined the king's attitude towards the coalitionists were his claims to those areas of Armenia that Tigranes II had taken away from the Parthians: Cassius Dio 36.1.1; 3.2.

35 Plut., Luc. 30.1-2; Cassius Dio 36.3.1-2; Memnon 38.8 (=FGrH IIIB, p. 366); Oros. 6.13.2; Debevoise 1938, 70-72; Ziegler 1964, 24-28. Many scholars (cf. Ziegler 1964, 25) express the view, based on Orosius (6.13.2), that Phraates III reached an agreement with Lucullus on recognising the Euphrates as the common border. Yet there is no basis to accept this source as reliable; cf. Liebmann-Frankfort 1969, $240-242$.

36 Cassius Dio 36.3.2-3.

37 Cf. Cassius Dio 36.45.3; Festus 16.3.

38 Dio 36.45.3; 51.1; Plut. Pomp. 33.6; Memnon 38.8 (=FGrH IIIB, p. 366); cf. Florus $1.40(=3.5)$; 1.46 (3.11); Oros. 6.13.2; Ziegler 1964, 28-32.

39 Appian, Mithr. 104.

40 Appian, Mithr. 104; Cassius Dio 36.51.1; 37.6.4. 
took place around 66/65 BCE. Phraates III kept his promise, supporting his son-in-law not only with his own troops, but also participating in person in his expedition against Tigranes II. After the initial successes, the campaign concluded with a rather unexpected finale. Despite the Parthian assistance, Tigranes the Younger was unable to defeat his father, and crossed to Pompeius' side. Yet his hopes to win the throne of Armenia in this way were dashed by Tigranes II's surrender to the Roman commander. Moreover, Tigranes the Younger's relations with Pompeius deteriorated on account of his conduct to the extent that he was imprisoned. ${ }^{41}$ Phraates III then asked Pompeius to free his sonin-law and to confirm the recognition of the Euphrates as the Parthian-Roman border. ${ }^{42}$ However, Pompeius' hands were no longer tied as the war with Tigranes came to a close, and not only did he turn Phraates down, but he also threatened him with war. ${ }^{43}$

Although these events scuppered the possibility of maintaining the conditions of the agreement of $66 \mathrm{BCE}$, especially regarding the regions upon which the Parthian king had claims, Phraates III's attitude during Rome's war with Mithradates VI and Tigranes II demonstrates that he spared no effort in taking any opportunity to realise his plans regarding Armenia. Neither had he given up hope of keeping it in the sphere of Parthian influence. This is confirmed by a reference by Cassius Dio noting that at the point when the fate of Armenia was being decided, Phraates III was appealing to Pompeius to keep Tigranes II on the throne of Armenia, hoping that the old ruler would one day stand at his side as an ally in the struggle against Rome. ${ }^{44}$ Although Phraates was not spectacularly successful in his contacts with Rome, an undoubted achievement was the fact that the Roman generals discerned the important role of the Parthian state in the region.

Tigranes II's son and heir Artavasdes II (55-34 BCE) was unstable in his political sympathies. Artavasdes supplied reinforcements to L. Licinius Crassus when the latter was preparing for an attack on the Arsacid kingdom, yet when it became clear that Crassus was not interested in closer collaboration, Artavasdes turned to Orodes II (57-38 BCE). The two rulers strengthened ties, and Artavasdes' daughter married Orodes II's son Pacorus. If Plutarch is to be believed, the wedding took place soon after Crassus' army had been routed by Parthian army at Carrhae. ${ }^{45}$ Yet the alliance with Orodes II did not stand the test of time, since Artavasdes soon again became interested in collaboration with Rome. In 36 he participated in Mark Antony's expedition against the ruler of Media Atropatene, which was under Arsacid command and was a very active supporter of the de facto Roman administrator of the East, but the failure of this campaign decided his fate. Under Cleopatra's influence, Antony blamed Artavasdes for his misfortunes, and during his next expedition to Armenia in 34 BCE used subterfuge to strip him of power and dispatched him and his family to Alexandria, where, in $30 \mathrm{BCE}$, he was murdered on the queen's orders. ${ }^{46}$ In Artavasdes II's place, the Arme-

41 Plut. Pomp. 33.1-5; Appian, Mithr. 104-105; Cassius Dio 36.51.3-53.6.

42 Plut. Pomp. 33.6; Cassius Dio 37.5.2.

43 Plut. Pomp. 33.6; Cassius Dio 37.5.2-6.3.

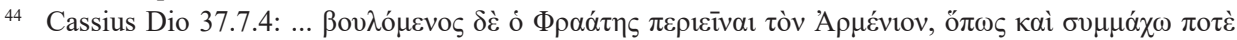

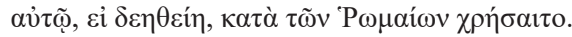

45 Plut. Crass. 33.2-4; Debevoise 1938, 92-93.

46 Josephus, BJ 1.363; AJ 15.104; Tac. Ann. 2.3.2; Plut. Ant. 50.4; Cassius Dio 49.39.2-40.4; Oros. 6.19.3. 
nian aristocracy placed his son, Artaxes (Artaxias) II, on the throne; yet, faced with danger from Antony's army, Artaxes left the country and sought refuge in the court of the Parthian king, Phraates IV. ${ }^{47}$

The political situation at the time was unfavourable for both leaders, since not only the whole of Armenia, but also Media Atropatene found themselves under Antony's rule. ${ }^{48}$ Only when Antony, as a result of preparations to fight with Octavian for power in Rome, was forced to withdraw many of his units from the occupied lands, did Artaxes have the opportunity to regain the throne, something in which he was aided by Phraates IV. ${ }^{49}$ As the situation in Rome stabilised, Octavian Augustus was able to focus his attention on the East. Since he did not intend to tolerate an Armenian ruler hostile to Rome,$^{50}$ he took a number of political steps in the neighbouring lands to threaten Artaxes' position. ${ }^{51}$ In $20 \mathrm{BCE}$, given his lack of success in these efforts, he sent his stepson Tiberius to Armenia with the mission of enthroning Tigranes (III), ${ }^{52}$ one of Artaxes II's brother, who was friendly to Rome. As news of his approach arrived, Artaxes II was murdered. ${ }^{53}$ The success of Tiberius' mission was also significant for Roman-Parthian relations, since a complicated domestic situation forced Phraates IV to form an agreement with Rome and abandon his influences in Armenia and Media Atropatene. ${ }^{54}$ Tigranes III was therefore able to rule for many years. ${ }^{55}$ Rome's policy in Armenia contributed to the formation of a strong pro-Parthian alliance there, whose support allowed Tigranes IV to seize power following his father's death without seeking Roman approval. ${ }^{56} \mathrm{He}$ was also aided by the then king of the Parthia, Phraataces (= Phraates V). Tigranes IV's hostile attitude towards Rome led Augustus to intervene in Armenia, resulting in Artavasdes coming to the Armenian throne. ${ }^{57}$ Yet his reign was toppled by the pro-Parthian alliance. In $1 \mathrm{CE}$ when Tigranes IV perished in a war with barbarians Augustus entrusted his adopted son, Gaius Caesar, with restoring Roman influences in Armenia. In the first phase, his mission brought beneficial effects to Rome: the Roman candidate Ariobarzanes was enthroned in

47 Josephus, $A J$ 15.105; Cassius Dio 49.39.6-40.1.

48 Plut. Ant. 53.6; Cassius Dio 49.40.2; 44.2; 44.4.

49 Tac. Ann. 2.3.2; Cassius Dio 49.44.4; 51.16.2.

50 Cf. Cassius Dio 51.16.2.

51 These moves included strengthening Roman influences in the vassal states surrounding Armenia by placing rulers, hostile to Artaxes, on their thrones; cf. Dąbrowa 1983, 41.

52 There are some problems with numbering of the Armenian rulers, what makes that in various publications the same kings have different numerals, cf. Bendschus 2018, 14, note 20.

53 Res Gestae divi Augusti 27.1; Vell. Pat. 2.94.2; Josephus, AJ 15.105; Tac. Ann. 2.3.2; Suet. Tib. 9.1.; Cassius Dio 54.9.4-5. Velleius Paterculus erroneously writes that Tiberius inserted Artavasdes on the throne of Armenia (... in potestatem populi Romani regnum eius Artauasdi dedit). Cf. Chaumont 1976, 75-76.

54 Suet. Aug. 21.3.

55 He was probably in power until c. 8 BCE: Kovacs 2016, 28. Written sources do not contain sufficient chronological data to precisely date the rule of the various rulers of Armenia from the period of Augustus' reign, and therefore the dates given with their names should be treated as approximate. The coins that some of them minted generally do not have any dates; cf. Kovacs 2016, 28-31. From Tigranes III' reign there are known several emissions of his coins. For their identification and classification, see Bendschus 2018, 32-37, nos. 1-12, 44.

56 Dio 55.9.4; Kovacs 2016, 28. Cf. Chaumont 1976, 76. See also Bendschus 2018, 37-39, nos. $13-17$.

57 Tac. Ann. 2.4.1. 
Armenia, ${ }^{58}$ while Phraataces agreed to a pact whereby he would refrain from interfering in the country's affairs. ${ }^{59}$ But the situation was again complicated by Ariobarzanes' death after a brief reign. After him, according to Tacitus, Erato came to power, the sister and the wife of Tigranes IV. ${ }^{60}$ Next, in rapid succession, Ariobarzanes' son Artavasdes IV $(\mathrm{V})^{61}$ and Tigranes $\mathrm{V}^{62}$ came to the throne. Yet neither of them was able either to remain in power for long or to gain the affection of their Armenian subjects, mostly because of their foreign origin. ${ }^{63}$ As a result, Rome's rivalry with the Parthians for Armenia meant that halfway through the first decade CE it found itself outside of the Roman sphere of influence. Wishing to curb Phraataces' influence in Armenia, Rome exploited a crisis within Parthia caused by his conflict with the aristocracy. At the request of aristocrats hostile to the king, Augustus sent Vonones to Parthia, ${ }^{64}$ one of Phraates IV's sons who had been in Rome since 10 BCE. ${ }^{65}$ His mission was unsuccessful, since his style of rule soon encountered strong opposition from the section of the aristocracy supporting Artabanus (III), who came from a different line of Arsacids. ${ }^{66}$ Forced to flee, Vonones found refuge in Armenia, where without delay he claimed the vacant throne. ${ }^{67}$ From the outset, Artabanus prioritised not only Armenia, but also other lands to which the Arsacids laid claim. The presence of Vonones in Armenia was not beneficial either to Rome or to Artabanus, since they were threatened by a mutual conflict. ${ }^{68}$ Emperor Tiberius therefore sent Germanicus eastwards in $18 \mathrm{CE}$ to take control of the political situation in Armenia. ${ }^{69}$ A favourable circumstance for him was the internal problems with which Artabanus was

58 Cassius Dio 55.10a.5; 10a.7; Kovacs 2016, 29.

59 Tac. Ann. 2.4.1; Cassius Dio 55.10a.4; cf. Vell. Pat. 2.101.1-3.

60 Tac. Ann. 2.4.2; Cassius Dio 55.10a.5. The chronology of the rulers of Armenia ascertained on the basis of numismatic sources is slightly different. They show that Tigranes IV was in power twice (on the second occasion approved by Rome, together with his sister as well as wife, Erato - cf. Chaumont 1976, 77; Kovacs 2016, 29) - and that Erato ruled again independently after a gap of more than a decade, following Tigranes V: Kovacs 2016, 30-31. According to Bendschus $(2018,21)$ it is not excluded that for political reasons Erato married Tigranes V.

61 Cassius Dio 55.10a.7.

62 Res Gestae divi Augusti 27.2; Josephus, AJ 18.139; Tac. Ann. 6.40.2; Kovacs 2016, 30; Bendschus 2018, 13-14, 18-31, 40-41, nos. 18-20.

63 Chaumont 1976, 81-83.

${ }^{64}$ Res Gestae divi Augusti 33; Josephus, AJ 18.46; Tac. Ann. 2.1.1; 2.1-2; cf. Suet. Tib. 49.2. See PIR ${ }^{2}$ V 994; Karras-Klapproth 1988, 210-213; Eck - Caballos - Fernández 1996, 106-107.

65 Res Gestae divi Augusti 32.2; Strabo 6.4.2 (288); 16.1.28 (748); Vell. Pat. 2.94.4; Josephus, AJ 18.42; Tac. Ann. 2.1.2; Suet. Aug. 21.3; 43; Just. 42.5.12; Oros. 6.21.29; Eutrop. 7.9; Festus 19.1. The exact date of this event is unknown. The given date should be treated as a terminus ante quem marking the moment of M. Titius' departure from the position of governor of Syria, as he was entrusted with the mission of caring for Phraates IV's family members: Dąbrowa 1998a, 18-19. Velleius Paterculus erroneously identifies this event with Tiberius' mission in 20 BCE.

66 Josephus, AJ 18.48; Tac. Ann. 2.3.1.

67 Josephus, $A J$ 18.50; Tac. Ann. 2.4.2.

68 SC de Cn. Pisone patre, ll. 39-45 (cf. Eck - Caballos - Fernández 1996, 166); Josephus, AJ 18.51; Tac. Ann. 2.4.3.

69 SC de Cn. Pisone patre, ll. 30-32 (cf. Eck - Caballos - Fernández 1996, 161-162); Tac. Ann. 2.43.1. One motive might have been the desire to remove Artabanus III's son Orodes, who, according to Josephus ( $A J$ 18.52), was placed on the throne of Armenia by his father. The credibility of this source is doubtful, however. 
struggling. This made it easy for Germanicus to place a member of the royal dynasty of Pontus on the throne, who proved very popular; as its ruler he took the name Artaxias (III). ${ }^{70}$ Artabanus accepted this decision and, keen to follow suit in improving relations with Rome, proposed concluding a friendship treaty between the two empires. Germanicus did not adopt a position in keeping with Artabanus' intentions, yet neither did he refuse a direct meeting with the king. This resulted in Rome's removal of Vonones from Armenia, and thus reduced tension in the relations between the two states. ${ }^{71}$

Artabanus III only briefly reconciled himself to the loss of influence in Armenia. His determination in this respect is demonstrated by his actions after the death of Artaxias III in $34 \mathrm{CE}$, when he entered Armenia and placed his son, Arsaces, on the throne there. ${ }^{72}$ According to Cassius Dio, he also took control of Cappadocia. ${ }^{73}$ Soon afterwards, he sent an envoy to Rome, who, in the presence of Emperor Tiberius, accounted for his actions. According to Tacitus, Artabanus III demanded not only the return of the properties belonging to Vonones, but also that Rome acknowledge his claims to Armenia and other lands in the East, because they had once belonged to the Achaemenid state and the empire of Alexander the Great, whose heir he saw himself as. ${ }^{74}$ Tacitus himself regarded these claims as ludicrous, ${ }^{75}$ but their ideological significance leaves no doubt that they derived from a clearly formulated political programme. Contrary to Tacitus' view, Emperor Tiberius' reaction shows that he treated these threats very seriously, as he took a number of steps with the intention of regaining control over Armenia. Unwilling to engage Rome in armed conflict, he used the full range of political means available to him. He decided to take advantage of the help of Mithradates the Iberian, the ruler of Armenia's neighbour Caucasian Iberia, promising him the crown of Armenia, ${ }^{76}$ as well as to send to Parthia, on the request of aristocrats hostile to Artabanus, the next of Phraates IV's sons in Rome, Phraates. ${ }^{77}$

Armenia was the focal point of the situation. Artabanus sent his son Orodes there with considerable forces to fight with the Iberians. ${ }^{78}$ Yet the campaign was unsuccessful, despite the king's personal involvement. The brother of Mithradates the Iberian, Pharasmenes, who took control of Armenia, managed to block all the roads leading to it from Transcaucasia. He therefore prevented Artabanus from securing military support

70 Strabo 12.3.29 (C 556); cf. SC de Cn. Pisone patre, ll. 43-44. The event was also commemorated by the issue of didrachmae and drachmae struck by one of the Roman mints in the East, probably in Caesarea (Cappadocia). The reverses of both types of coin depict the scene of Germanicus placing a tiara on the head of Artaxias. The coins also feature a legend referring to this scene: Obv. GERMANICUS CAESAR TI AVG F COS II; Rev. ARTAXIAS / GERMANICUS: RPC I, no. 3629-3630. Armenian issues of Artaxias are also known with an image of a tiara on the obverse as well as legends whose contents express his vassal relationship with Rome: Kovacs 2014, 19-25; Kovacs 2016, 31-32. Cf. Traina - Buongiorno 2020, $102-103$.

71 Tac. Ann. 2.58.1-2.

72 Tac. Ann. 6.31.1; Cassius Dio 58.26.1; cf. Suet. Tib. 41; Philostr. v. Apoll. 2.2.

73 Cassius Dio 58.26.1.

74 Tac. Ann. 6.31.1: ... simul veteres Persarum ac Macedonum terminos, seque invasurum possessa Cyro et post Alexandro ...

75 Tac. Ann. 6.31.1: ... per vaniloquentiam ac minas iaciebat.

76 Tac. Ann. 6.32.2.

77 Tac. Ann. 6.31.1-2; Cassius Dio 58.26.2.

78 Tac. Ann. 6.33.2; 34.1. 
from this side, without which he was unable to force the Iberians out of Armenia. ${ }^{79}$ Owing to the failure of the battles with the Iberians, a section of the Parthian aristocracy succumbed to Roman propaganda and opposed Artabanus, supporting Tiridates (II), the latest pretender to the Arsacid throne sent from Rome, ${ }^{80}$ who took control of Mesopotamia and forced Artabanus to flee to the eastern provinces of the state. Regaining power and control over Mesopotamia enabled Artabanus to make contact with the governor of Syria, L. Vitellius, previously an active supporter of the aforementioned Parthian pretenders in Rome's name. ${ }^{81}$ The king and governor met, on the latter's initiative, in spring $37 \mathrm{CE}$ on the Euphrates. ${ }^{82}$ The development of events suggests that Mithradates the Iberian remained on the throne of Armenia. Artabanus, meanwhile, probably obtained the city of Nisibis and the surrounding area, part of Armenia, ${ }^{83}$ as well as recognition of the Taurus mountain range as the border line. ${ }^{84}$ In the context of the complicated internal situation in the Arsacid state, his success was to be recognised by Rome as its sole partner for diplomatic discussions. The price of this success was that his son Darius was sent to Rome as a hostage. ${ }^{85}$

Artabanus III's pact with L. Vitellius proved to be short-lived. The reasons for this were the events both in Rome, where in spring 37 CE Gaius came to the throne, espousing a radically different approach to questions of eastern policy than that of Tiberius, and in Parthia, where in 39 CE Artabanus III's murder at the hands of his brother Vardanes resulted in internal battles for power between him and Gotarzes. ${ }^{86}$ In the East, Gaius restored the throne to many vassal rulers ${ }^{87}$ but had Mithradates the Iberian imprisoned without naming his successor. ${ }^{88}$ Mithradates' return to the Armenian throne was inspired by Emperor Claudius, with military support from Pharasmenes, king of Iberia ${ }^{89}$ Given the evident threat of Parthian interests, the rival pretenders to the Arsacid throne reached an agreement which gave Vardanes a free hand to act in Armenian affairs. ${ }^{90}$ Vardanes intended to reclaim Armenia, but his plans in this regard were dashed by the governor of Syria, Vibius Marsus, who threatened to go to war with him. ${ }^{91}$ Soon afterwards, longlasting battles in the Arsacid state again began, ending for a time only when Vologeses I came to power (51-78 CE). ${ }^{92}$

From the beginning of his reign, Vologeses took steps to strengthen the Arsacids' position outside of the state's borders. One of his first moves in this direction was to hand

79 Cf. Tac. Ann. 6.33.1-36.2.

80 Tac. Ann. 6.32.3; 37.1-4.

81 Josephus, AJ 18.101; Suet. Vit. 2.4; Cassius Dio 59.27.3. See Dąbrowa 2002.

82 Josephus, $A J$ 18.101-105; Suet. Cal. 14.3.; Vit. 2.4 ; Cassius Dio 59.27.3.

83 Cf. Josephus, AJ 20.68.

84 Cf. Tac. Ann. 12.49.2.

85 Josephus, AJ 18.102; Suet. Cal. 19.2; cf. Cassius Dio 59.17.5. According to Cassius Dio, Artabanus III sent several of them: Cassius Dio 59.27.3.

86 Tac. Ann. 11.8.1-4.

87 Tac. Ann. 11.8.1; Cassius Dio 60.8.1.

88 Tac. Ann. 11.8.1; Seneca, de tranq. anim. 11.12; Cassius Dio 60.8.1.

89 Tac. Ann. 11.9.1-2.

90 Tac. Ann. 11.9.3-4.

91 Tac. Ann. 11.10.1.

92 See Tac. Ann. 10.1-4; 12.10.1-14.4. 
rule over Media Atropatene to one of his brothers, Pacorus. ${ }^{93}$ When rivalry for the throne in Armenia ensued between Mithradates the Iberian and his nephew Rhadamistus, the son of the Iberian king, Vologeses decided to exploit the conflict to install his brother Tiridates on the throne of Armenia. ${ }^{94}$ The Parthian army captured Armenia without undue resistance in late $52 \mathrm{CE}$, yet problems with provisions led them to withdraw in winter of the same year, allowing Rhadamistus to occupy part of its territory. ${ }^{95}$ However, the population soon rebelled against his rule, forcing him to flee, ${ }^{96}$ and this enabled Tiridates to regain control over the areas that he had previously lost. News of these events reached Rome only in late $54 \mathrm{CE},{ }^{97}$ but Nero's reaction was immediate, ordering preparations for war in Armenia..$^{98}$ On the cusp of this conflict, Rome achieved an obvious bonus: in early $55 \mathrm{CE}$, Vologeses was faced with a rebellion by a son of Vardanes whose name is unknown, ${ }^{99}$ forcing him to leave Tiridates to his own devices. As a result, the threat of war with a powerful opponent persuaded Vologeses to refrain from actions that might have contributed to an escalation of tension between the two states. ${ }^{100}$ Despite the lack of support from Vologeses, Tiridates was able to hold on to power in this part of Armenia, thanks to the support of the pro-Parthian population, until as late as $58 \mathrm{CE} .{ }^{101}$ In this year Tiridates, wishing to expand the lands he controlled, attacked areas in the Roman sphere of influence. ${ }^{102}$ The Romans sent their allies to fight him, putting Tiridates in danger of losing power in Armenia - a threat that was even more real since Vologeses was unable to support him at the time because of his involvement in battles in Hyrcania. ${ }^{103}$ Tiridates attempted, unsuccessfully, to open talks with Corbulo, the commander-in-chief of the Roman army in Armenia. This resulted in a resumption of fighting, leading to the capture and razing of the capital of Armenia, Artaxata, and ultimately to Tiridates being driven out of Armenia. ${ }^{104}$ Corbulo's successes meant that in $60 \mathrm{CE}$ he was able to place the Roman nominee, Tigranes VI, on the throne. ${ }^{105}$ To prevent Tiridates taking control of Armenia again, it was divided into parts, whose security was entrusted to various vassal rulers. ${ }^{106}$ Vologeses, absorbed in events in Hyrcania and Adiabene, remained passive in

93 Josephus, AJ 20.74; Tac. Ann. 15.2.1; 15.31.1.

94 Josephus, AJ 20.74; Tac. Ann. 12.50.1.

5 Tac. Ann. 12.50.2.

96 Tac. Ann. 12.50.2-51.4.

97 Tac. Ann. 13.6.1.

98 Tac. Ann. 13.7.1; 13.8.2.

99 Cf. Tac. Ann. 13.7.2; Schippmann 1980, 55; Karras-Klapproth 1988, 189. According to some scholars, Vologeses fought with his own son, named Vardanes, cf. Chaumont 1976, 99; Bivar 1983, 81; PIR 2 V 260. The reason for the difference in opinions is the various versions of this passage from the Annals preserved in manuscript tradition, meaning that it can be interpreted in two ways: Chaumont 1976, 99, note 154; KarrasKlapproth 1988, 189, note 1.

100 Tac. Ann. 13.9.1-2.

101 Cf. Tac. Ann. 13.37.1.

102 Tac. Ann. 13.37.1.

103 Tac. Ann. 13.37.2-5; 14.25.2.

104 Tac. Ann. 14.26.1.

105 Josephus, BJ 2.222; AJ 18.139-140; Tac. Ann. 14.26.1; 15.1.1; Bendschus 2018, 41-43, nos. 21-25.

106 Tac. Ann. 14.26.1-2. 
the question of Armenia until $62 \mathrm{CE} .{ }^{107}$ At this point, his position changed radically as a result of Tigranes V's attack on Adiabene. ${ }^{108}$ Vologeses responded by declaring his full support for Tiridates in the struggle for Armenia. Yet the king's actions did not bring great successes, since the Parthian troops were unable to capture Tigranocerta, where Tigranes had taken refuge together with the Roman forces supporting him. Vologeses was keen to avoid direct conflict with Rome, and agreed to Corbulo's proposal to send a delegation to Nero regarding the Parthians' regaining authority over Armenia. Yet the news that returned to Vologeses was not good. The refusal to satisfy his demands meant that the rivalry over Armenia went from being a local conflict into an overt war between Rome and the Parthians. ${ }^{109}$ Nero entrusted command in the war in Armenia to L. Caesennius Paetus, while Corbulo was to defend Syria from a potential Parthian attack. Yet the scope of the operations did not extend beyond the Euphrates. Mistakes made by Caesennius Paetus soon gave Vologeses the opportunity to gain a spectacular victory over him. Besieged in Rhandeia and unable to secure rapid support, the Roman commander agreed not only to surrender it, but also to evacuate other fortresses occupied by Roman forces and to leave Armenia with his troops. ${ }^{110}$ It was also decided that Vologeses would send another legation to Nero to present the situation and the conditions for an agreement. Soon afterwards, but still before the mission was sent to Rome, Vologeses simultaneously agreed a pact with Corbulo. The king consented to evacuate his forces from Armenia and to leave its throne vacant until Nero reached a decision. ${ }^{11}$

Vologeses' legation reached Rome in spring $63 \mathrm{CE}$ with the expectation of recognition of the state of affairs, i.e. confirmation of Parthian authority over Armenia and Tiridates' rule. ${ }^{112}$ Yet the kings' envoys were rebuffed, and Nero ordered that fighting be renewed. The engagements that followed were not too intensive, however, as Corbulo, entrusted with command by the emperor, realised that prolonging the conflict made little sense.Several days later, representatives of the two sides met at Rhandeia and agreed the conditions for the end of the war: Tiridates was to place his royal diadem before an image of the emperor, to receive it back from Nero later in Rome. The ceremony of the placing of the diadem took place a few days later, in the presence of the Roman army. ${ }^{113}$ Both sides respected the rules of the agreement for the next few decades, until the time of Trajan, when battles for Armenia were resumed. Nevertheless, this accord ensured that the Armenian line of the Arsacid dynasty would rule in the country until the 4th century CE.

107 The reason for Adiabene's involvement was that its king, Izates II, was accused by the supporters of his brother Monobazus of a hostile attitude towards the Parthians. Since Adiabene neighboured with Armenia, the king's intervention was essential for monitoring Tigranes V's actions: Josephus AJ 20.75-91. Yet it did not lead to a change on the Adiabene throne, since Izates' natural death soon afterwards and the assumption of power by Monobazus, who was loyal to Vologeses, contributed to removal of the source of the Parthian ruler's concerns: Josephus, AJ 20.92.

108 Tac. Ann. 15.1.2; Cassius Dio 62.20.2.

109 Tac. Ann. 15.7.1; Cassius Dio 62.20.4-21.2.

110 Tac. Ann. 15.14.3; Cassius Dio 62.21.2-3; cf. Eutrop. 7.14.

111 Tac. Ann. 15.17.3; Cassius Dio 62.22.2-3.

112 Tac. Ann. 15.24.1-2; Cassius Dio 62.22.3-4.

113 Tac. Ann. 15.29.1- 3; Cassius Dio 62.23.3-4. Formal ceremony of putting the diadem on head of Tiridates by Nero had place in 66 CE when brother of Vologeses I arrived to Rome: Cassius Dio 63.4.3-5.4. 
The picture of the Arsacids' efforts to gain influence and power in Armenia in the period from the end of the 2nd century BCE until the agreement of Rhandeia contains so many diverse details that its most important elements are sometimes blurred. The intensiveness of these endeavours as well as the consistency with which the various rulers of Parthia pursued them leave no doubt that from the time of Mithradates II, Armenia occupied an important place in the Arsacids' external policy.

Three phases can be identified in the Arsacids efforts to capture Armenia. The first came with the Artaxiad dynasty's rule in Armenia. Although the Parthian kings, from Mithradates II until Phraates IV, tried to bring the rulers of this dynasty under their control, be it with the use of force or through dynastic marriages, they did not manifest a desire to annexe their state. In certain situations they even defended the Artaxiads' rights to the crown, supporting members of the dynasty in the struggle against Roman candidates. The reason for this was no doubt their conviction that it was a much more politically favourable situation to have a dependent Armenia ruled by a local dynasty which enjoyed the support and affection of its subjects, than to bring their own candidates to its throne, whose rule would subsequently require constant support. The second phase, which we can call a transition period, was characterised by the Arsacids' struggle with the rulers of Armenia placed on the throne by Rome. Antony's removal of the Artaxiads' power in 34 BCE meant that the Parthian kings were happy to support the Armenian opposition who sympathised with the Arsacids, in their fight against foreign nominees, but they also renewed their claims to Armenia in Rome. Their avoidance of open confrontation there was dictated by unrelenting internal problems, which forced the kings of Parthia to accept the rulers of Armenia imposed by Rome. This phase also includes the episode concerning the accession to the throne of Vonones, son of Phraates IV, whose presence in the state was for both sides an obstacle hampering good mutual relations. The third phase, encompassing the years between 34 and $63 \mathrm{CE}$, was characterised by a marked change in the Arsacids' position towards Armenia. The Parthian kings aspired to place members of their own dynasty on the throne there. The first to make such an (unsuccessful) attempt was Artabanus III. For Vologeses I, installing Tiridates on the throne of Armenia and defending his position became a matter not only of personal honour, but also of dynastic interest. His engagement resulted in success: after many years of fighting, Nero awarded the Arsacids the right to rule Armenia. They were in power there as late as the 4th century $\mathrm{CE}$, although from a formal point of view the king of Armenia was a vassal of Rome. The so-called Treaty of Rhandeia also contributed to stability of the situation not only in Armenia itself, but also in relations between Rome and the Parthian state.

The tenacity which the Arsacids brought to Armenian issues resulted not just from its strategic location, with an impact on the security of other neighbouring lands (Sophene, Adiabene, Media Atropatene), or of Mesopotamia, which belonged to the Parthians. Without underestimating the significance of this factor, we can also point to another motif in their efforts to make this state dependent on them. This is mentioned at least two times by Tacitus in the Annals: first in his account of Artabanus III's legation to Rome, ${ }^{114}$ and later, describing the phase of war with Armenia during Nero's rule, in which Vologeses I

114 Tac. Ann. 6.31.1. 
joined the battle. ${ }^{115}$ In Artabanus III's name, the envoys demanded acknowledgement of his claims to areas that in the past had belonged to the Achaemenid state and Alexander the Great. The historian's account suggests that this demand was not taken seriously in Rome. It was also repeated, in a slightly different form, by the delegates of Vologeses I. It was the emanation of the ideological premises of the Arsacids' external policy programme, probably framed by Mithradates I and extended by his successors. ${ }^{116}$ The programme was rooted in the tradition of the Achaemenids, as the Parthian monarchs regarded themselves as heirs to their greatness.

In demanding that Rome recognise the border on the Euphrates, Mithradates II certainly anticipated that this would be tantamount to a commitment by his opponent not to interfere in the affairs of the provinces under Arsacid rule. We can therefore assert that his interference in Armenia, which permanently connected the fortunes of the two states, resulted from the external policy programme in Western Asia, which served to bolster the power of the Arsacid Empire. ${ }^{117}$ As a result of Rome's expansion in Anatolia, the Parthian rulers encountered in their path a rival who not only did not want to accord them exclusive rights to domination in the areas lying beyond the Euphrates line, but also became a threat to the security and integrity of the Arsacid state. Consequently, in the external policy of Mithradates II's successors, both elements, security and expansion, gained equal significance, determining the course of their political and military actions towards both Armenia and the neighbouring lands.

\section{BIBLIOGRAPHY}

Badian, E. (1959), Sulla's Cilician Command, Athenaeum 37: 279-303.

Bellinger, A. R. (1948-1949), Seleucid Dura: The Evidence of the Coins, Berytus 9: 51-67.

Bendschus, T. (2018), Tigranes V. und seine Münzen. Armenische Herrscherlegitimation des frühen 1. Jhdts. n. Chr. im Spiegel der numismatischen Zeuginisse, Numismatische Zeitschrift 124: 9-54.

Bivar, A. D. H. (1983), The Political History of Iran under the Arsacids, in: E. Yarshater (ed.), The Cambridge Ancient History of Iran, vol. III, part 1: The Seleucid, Parthian and Sasanian Periods, Cambridge: 21-99.

Börm, H. (2019), Die Grenzen des Grosskönigs? Überlegungen zur arsakidisch-sasanidischen Politik gegenüber Rom, in: F. Schleicher et al. (eds.), Iberien zwischen Rom und Iran. Beiträge zur Geschichte und Kultur Transkaukasiens in der Antike, Stuttgart: 99-122.

Cagniart, P. F. (1991), L. Cornelius Sulla in the Nineties: A Reassessment, Latomus 50: 285-303.

Chaumont, M.-L. (1976), L'Arménie entre Rome et l'Iran, I. De l'avèvement d'Auguste a l'avènement de Dioclètien, $A N R W$ II,9.1, Berlin-New York: 71-194.

Chaumont, M.-L. (1985-1988), a propos des premières interventions Parthes en Arménie et des circonstances de l'avènement de Tigrane le Grand, Acta Antiqua 31: 13-25.

115 Tac. Ann. 12.50.1. Cf. also Tac. Ann. 15.1.1-2.3.

116 Cf. Neusner 1963; Wolski 1966.

117 It seems that ideological and political aims of this programme were valid until the fall of the Arsacid state, see Dąbrowa 1984, 149-164. Cf. Chaumont 1985-1988, 19-20. 
Dąbrowa, E. (1983), La politique de l'État parthe à l'égard de Rome - d'Artabane II à Vologèse I (ca 11 - ca 79 de n.è.) et les facteurs qui la conditionnaient, Kraków.

Dąbrowa, E. (1984), Le programme de la politique en Occident des derniers Arsacides. Essai de reconstitution, Iranica Antiqua 19: 149-165.

Dąbrowa, E. (1998a), The Governors of Roman Syria from Augustus to Septimius Severus, Bonn.

Dąbrowa, E. (1998b), Philhellên. Mithridate Ir et les Grecs, Electrum 2: 35-44.

Dąbrowa, E. (2002), '... ostentasse Romana arma satis ...': The Military Factor in Roman-Parthian Relations under Augustus and Tiberius, in: Ph. Freeman et al. (eds.), Limes XVIII: Proceedings of the XVIIIth International Congress of Roman Frontier Studies Held in Amman, Jordan (September 2000), Oxford: 275-279.

Dąbrowa, E. (2005), Les aspects politiques et militaires de la conquête parthe de la Mésopotamie, Electrum 10: 73-88.

Dąbrowa, E. (2006), The Conquests of Mithradates I and the Numismatic Evidence, Parthica 8: 37-40.

Dąbrowa, E. (2011), Studia Graeco-Parthica: Political and Cultural Relation between Greeks and Parthians, Wiesbaden.

Dąbrowa, E. (2018), Arsacid Dynastic Marriages, Electrum 25: 73-83.

Debevoise, N. C. (1938), a Political History of Parthia, Chicago, Ill.

Del Monte, G. F. (1997), Testi dalla Babilonia ellenistica, vol. I: Testi cronografici, Pisa-Roma.

Eck, W., Caballos, A., Fernández, F. (1996), Das senatum consultum de Cn. Pisone patre, München.

Edwell, P. M. (2008), Between Rome and Persia: The Middle Euphrates, Mesopotamia and Palmyra under Roman Control, London-New York.

Geller, M., Traina, G. (2013), "Tigranu, the Crown Prince of Armenia": Evidence from the Babylonian Astronomical Diaries, Klio 95: 447-454.

Hackl, U., Jacobs, B., Weber, D. (eds.) (2010), Quellen zur Geschichte des Partherreiches. Textsammlung mit Übersetzungen und Kommentaren, vol. 2, Göttingen-Oakville, CT.

Huber, I., Hartmann, U. (2006), ,Denn ihrem Diktat vermochte der König nicht zu wiedersprechen... ‘ Die Position der Frauen am Hof der Arsakiden, in: A. Panaino, A. Piras (eds.), Proceedings of the 5th Conference of the Societas Iranologica Europea Held in Ravenna, 6-11 October 2003, vol. 1: Ancient and Middle Iranian Studies, Milano: 485-517.

Karras-Klapproth, M. (1988), Prosopographische Studien zur Geschichte des Partherreiches auf der Grundlage antiker literarischer Überlieferung, Bonn.

Kovacs, F. L. (2014), Artaxias III and a Numismatic Enigma, Armenian Numismatic Journal, Ser. II, 10: $19-25$.

Kovacs, F. L. (2016), Armenian Coinage in the Classical Period, Lancaster, PA-London.

Liebmann-Frankfort, Th. (1969), La frontière orientale dans la politique extérieure de la République romaine depuis le traité d'Apamée jusqu'à la fin des conquêtes asiatiques de Pompée (189/8-63), Bruxelles.]

Luther, A. (2018), Zu den Dokumenten aus Avroman, Gymnasium 125: 155-177.

Minns, E. H. (1915), Parchments of the Parthian Period from Avroman in Kurdistan, JHS 35: 22-65.

Neusner, J. (1963), Parthian Political Ideology, Iranica Antiqua 3: 40-59.

Olbrycht, M. J. (2010), The Early Reign of Mithradates II the Great in Parthia, Anabasis 1: 144-158.

Sachs, A. J., Hunger, H. (1989), Astronomical Diaries and Related Texts from Babylonia, vol. II: Diaries from 261 B.C. to 165 B.C., Wien.

Sachs, A. J., Hunger, H. (1996), Astronomical Diaries and Related Texts from Babylonia, vol. III: Diaries from 164 B.C. to 61 B.C., Wien.

Schippmann, K. (1980), Grundzüge der parthischen Geschichte, Darmstadt.

Schottky, M. (1989), Media Atropatene und Gross-Armenien in hellenistischer Zeit, Bonn.

Sullivan, R. D. (1978), Papyri Reflecting the Eastern Dynastic Network, $A N R W$ II.8, Berlin-New York: 908-939.

Sumner, G. V. (1978), Sulla's Career in the Nineties, Athenaeum 56: 395-396. 
Traina, G. (2007), Les Arméniens entre l'Iran et le monde gréco-romain (Ve siècle av. J.-C.-vers 300 ap. J.-C.), in: G. Dédéyan (ed.), Histoire du peuple arménien, Toulouse: 101-162.

Traina, G., Buongiorno, P. (2020), L'imperium di Germanico, l'Armenia e l'Oriente, in: A. Galimberti, R. Cristofoli, F. Rohr Vio (eds.), Germanico nel contesto politico di età Giulio Claudia. La figura, il carisma, la memoria, Roma 2020, 99-122.

Welles, C. B., Fink, R. O., Gilliam, J. F. (1959), The Parchments and Papyri (The Excavations at DuraEuropos. Final Report V, part 1), New Haven, Mass.

Wolski, J. (1966), Les Achémenides et les Arsacides. Contribution à l'histoire de la formation des traditions iraniennes, Syria 43: 65-89.

Wolski, J. (1980), L'Armnie dans la politique du Haut-empire parthe (env. 175-87 av. n.é.), Iranica Antiqua 15: 251-267.

Wolski, J. (1983), Les rapports romano-parthes et la question de l'Arménie (I ${ }^{\mathrm{er}}$ siècle av. J.-C.- $\mathrm{I}^{\mathrm{er}}$ siècle ap. J.-C.), Ktema 8: 269-277.

Ziegler, K.-H. (1964), Die Beziehungen zwischen Rom und dem Partherreich. Ein Beitrag zur Geschichte des Völkerrechts, Wiesbaden. 